Volume 8. No. 8, August 2020

International Journal of Emerging Trends in Engineering Research

Available Online at http://www.warse.org/IJETER/static/pdf/file/ijeter04882020.pdf

https://doi.org/10.30534/ijeter/2020/04882020

\title{
The Effect of Additive on Pertalite to Increase Motorcycle Fuel Efficiency
}

\author{
Iswanto ${ }^{*}$, Wiwik Sumarmi ${ }^{2}$, Ribangun B. Jakaria ${ }^{3}$, Prantasi H. Tjahjanti ${ }^{1}$ \\ ${ }^{1}$ Department of Mechanical Engineering, Muhammadiyah University of Sidoarjo, Indonesia \\ ${ }^{2}$ Department of Industrial Engineering, Muhammadiyah University of Sidoarjo, Indonesia. \\ ${ }^{3}$ Faculty of Design Innovation \& Technology, Sultan Zainal Abidin University, Terengganu, Malaysia. \\ *Corresponding author: iswanto@umsida.ac.id
}

\begin{abstract}
Motorcycle in Indonesia use several types of Pertamina-produced fuel, such as premium (RON 88), Pertalite (RON 90), and Pertamax (RON 92). However, the price of gasoline-based fuels continues to increase there must be innovations to save fuel use. This study measures the level of efficiency between Pertalite mixed with additives with a motorcycle testing method in a stationary and moving state. Comparative research material was Pertalite with a mixture of additives and Pertamax. The study was conducted with a motorcycle filled with $300 \mathrm{ml}$ of fuel and left to run with a $4000 \mathrm{rpm}$ engine speed in a state of motion, then calculate the time to spend fuel. As a comparison, the motor was used in a moving condition and the mileage was measured until the fuel runs out. The results show a different level of consumption, which was lower consumption of Pertamax compared to using other fuels on an immovable motor. When the motorcycle was moving, Pertalite mixed with liquid additives was more efficient than pure Pertalite and Pertamax.
\end{abstract}

Key words: Additives; Pertalite; Efficiency; Motorcycle.

\section{INTRODUCTION}

The growth rate of motor vehicles is very high so that the need for fuel will also continue to increase [1], [2]. The most widely used fuels are fuels from fossils such as petroleum, coal, and natural gas [3]. Gasoline is a liquid mixture derived from petroleum and is mostly composed of hydrocarbons and is used in internal combustion engines as fuel [4]. In general, gasoline motor vehicles in Indonesia currently use several types of fuel produced by Pertamina, such as Premium, Pertalite, and Pertamax. Each type of fuel has a different octane number [2], [5].

There are many factors that affect the quality of combustion in the cylinder, including fuel quality (octane number), temperature, and injection pressure [6], [7]. The octane number shows the maximum amount of pressure applied to the engine before the gasoline spontaneously ignites [8], [9]. The higher the octane value, the higher the engine performance and fuel consumption efficiency [10]. At a certain pressure, the fuel will ignite because of the piston pressure which raises the temperature in the cylinder [11]. Ignition by a spark plug which is a result of unwanted pressure can cause knocking [9], [11].

Therefore, the use of fuel in accordance with the right compression ratio in the engine is expected to optimize engine performance, reduce damage, and more importantly, make fuel use efficient [8], [12]. One way to make efficient use of fuel is to add additives to the fuel [13], [14]. Research on the effect of pertalite-methanol blends on performance and exhaust emission of a four-stroke $125 \mathrm{CC}$ motorcycle engine shows that the addition of additives to the Pertalite in the form of methanol can improve engine performance and reduce exhaust emissions [1].

In this study, the additive used was FFPB, which is made from palm oil derivatives. This is a fuel conditioner that can increase an efficiency from an engine combustion activity to internal combustion [15]. FFPB has the benefit of saving fuel, increasing acceleration, increasing octane numbers, optimizing the combustion process, and eliminating detonation [14], [16].

The purpose of this study was to examine the effect of the addition of FFPB on Pertalite to the 4 stroke motor fuel efficiency. Secondly, if there is an effect on efficiency, this study examines whether the addition of FFPB is proportional to pure Pertamax.

\section{METHOD}

In this study, the testing was conducted using a Honda Supra $\mathrm{X} 125 \mathrm{R}$ motorcycle with specifications as in Table 1.

Table 1: Specification of Honda Supra X 125 R

$\begin{array}{ll}\text { Engine type } & \text { Four-stroke, air cooled, SOHC } \\ \text { Stroke Volume } & 124.8 \mathrm{cc} \\ \text { Bore x Stroke } & 52.4 \text { x } 57.9 \mathrm{~mm} \\ \text { Compression Ratio } & 9.0: 1 \\ \text { Max. Power } & 9.3 \mathrm{PS} / 7500 \mathrm{rpm}\end{array}$


Iswanto et al., International Journal of Emerging Trends in Engineering Research, 8(8), August 2020, 4052 - 4055

$\begin{array}{ll}\text { Max Torque } & 1.03 \mathrm{kgf.m} / 4000 \mathrm{rpm} \\ \text { Ignition } & \text { Carburettor-DC CDI }\end{array}$

The additive used was FFPB, which is a bio-nano product with the main element methyl esters from palm oil derivatives (RCOOCH3). Methyl esters from palm oil can be additives for gasoline fuels. When mixed into Pertalite, FFPB is able to break down hydrocarbons contained in fuel molecules so that it becomes a smaller chain for more perfect combustion [17], [18]. The use of FFPB was adjusted to the instructions for use, which was $1 \mathrm{ml}$ of FFPB used for 10 liters of fuel.

This study uses three types of fuels, namely: pure Pertalite, Pertalite mixed with FFPB and pure Pertamax. The test was done by turning on or running the motorcycle until the fuel runs out, so as much as $300 \mathrm{ml}$ of fuel was used, which was assumed to be sufficient, and the time required for testing was not too long.

\subsection{Testing Stage}

The preparation stage was continued with the testing process stage. In the testing process, there were two testing processes, namely the process of testing the consumption of fuel in a state of a silent motorcycle and the process of testing the consumption of fuel in a state of a moving motorcycle as follows.

\section{a. The static test}

The testing phase begins with preparing the motor to be used by tuneing up to the motor in standard conditions. The fuel in the tank and the carburetor was drained clean. Next, the researchers installed the rpm indicator tachometer on the motorcycle to be tested. After that, the motorcycle was filled with $300 \mathrm{ml}$ of pure Pertalite or Pertalite mixed with FFPB, or pure petamax. The motorcycle engine was then turned on and set to $4000 \mathrm{rpm}$ while calculating the time using the stopwatch until the fuel runs out.

\section{b. The moving test}

The testing process begins with preparing the motor to be used by tune up so that the motor was in a standard condition, then draining the fuel in the tank and the carburetor. The motorcycle was then filled with $300 \mathrm{ml}$ of pure Pertalite or Pertalite mixed with FFPB, or pure petamax. The motorcycle was then driven at a speed of $40 \mathrm{~km} / \mathrm{h}$ with a tolerance of \pm 5 $\mathrm{km} /$ hour. Next, the researchers calculated the distance traveled by using a speedometer until the motorcycle stopped (fuel ran out). Testing each type of fuel was carried out three times and then averaged to get more valid results.

\section{RESULT AND DISCUSSION}

This study aims to determine the level of efficiency of Pertalite mixed with FFPB. Data obtained from the comparison results of testing pure fuel consumption with fuel mixed with FFPB on a static and moving motorcycle.

\subsection{Static Test}

From all the results of testing the effectiveness of pure Pertalite, Pertalite mixed with FFPB and pure Pertamax in the state of a silent motorcycle obtained data as in Table 2.

Table 2: Consumption test results of several static motorcycle fuels

\begin{tabular}{lccc}
\hline \multicolumn{1}{c}{ Fuel } & $\begin{array}{c}\text { Amount of } \\
\text { Fuel (ml) }\end{array}$ & rpm & $\begin{array}{c}\text { Testing Results } \\
\text { (minutes) }\end{array}$ \\
\hline Pure Pertalite & 300 & 4000 & $31: 09: 29$ \\
Pertalite + FFPB & 300 & 4000 & $43: 05: 82$ \\
Pure Pertamax & 300 & 4000 & $46: 35: 74$ \\
\hline
\end{tabular}

Based on the data in Table 2, the study made a comparative graph of the level of consumption between pure Pertalite, Pertalite mixed with FFPB, and pure Pertamax based on the time that can be achieved on the condition of a motorcycle in a state of rest, as presented in Figure 1.

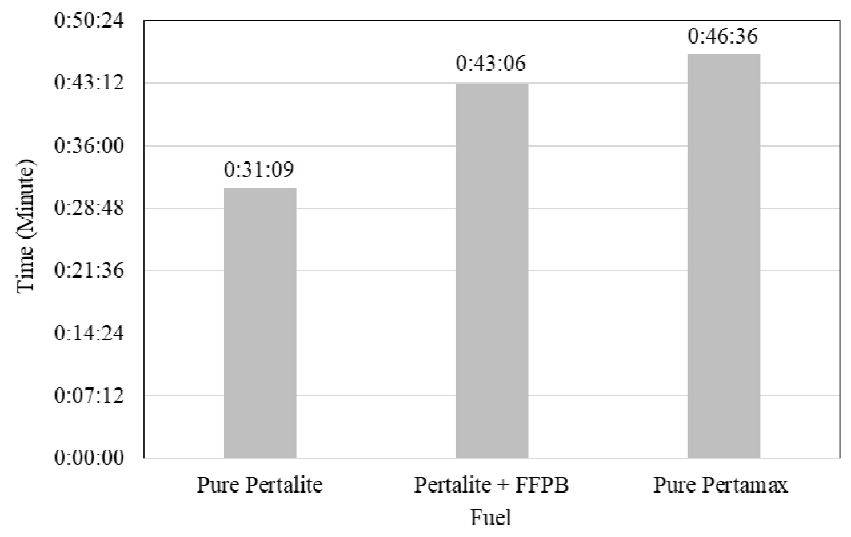

Figure 1: Comparison of fuel consumption rate based on time

From Table 1 and Figure 1, it can be explained that:

1) From the results of the first test carried out with pure Pertalite of $300 \mathrm{ml}$ and engine at $4000 \mathrm{rpm}$, the motorcycle needed 31 minutes more than 9 seconds to spend $300 \mathrm{ml}$ of pure Pertalite.

2) From the second test carried out testing using $300 \mathrm{ml}$ of Pertalite mixed with FFPB and engine at $4000 \mathrm{rpm}$, the motorcycle needed 43 minutes over 5 seconds to spend $300 \mathrm{ml}$ of Pertalite mixed with FFPB.

3) From the third test using $300 \mathrm{ml}$ pure Pertamax and engine at $4000 \mathrm{rpm}$, the motor needs 46 minutes and 35 seconds to spend $300 \mathrm{ml}$ pure Pertamax.

From the results of tests on the three types of fuel, it can be seen that Pertalite runs out in the fastest time compared to the other two fuels. This means that Pertalite was the most wasteful / most inefficient compared to the other two fuels.

Pertalite mixed with FFPB requires more time to spend this fuel compared with pure Pertalite. This means that the addition of FFPB to Pertalite can increase fuel efficiency. Pertalite mixed with FFPB has a $27.7 \%$ lower fuel 
Iswanto et al., International Journal of Emerging Trends in Engineering Research, 8(8), August 2020, 4052 - 4055

consumption than using pure Pertalite. This happens because the main element contained in FFPB, namely methyl ester, was able to break the hydrocarbon chain present in Pertalite so that the hydrocarbon chain becomes shorter. When combustion occurs in the combustion chamber, Pertalite mixed with methyl ester from FFPB will burn evenly so that it does not occur too early or too late which often occurs in the engine. Thus, the combustion process was more perfect.

The longest time to spend fuel occurs in pure Pertamax. This means that of the three types of fuel used, Pertamax has the highest efficiency. The addition of FFPB to Pertalite was still not comparable to Pertamax if used on a silent motorcycle.

\subsection{Moving Test}

After testing the level of consumption of pure Pertalite, Pertalite mixed with FFPB, and pure Pertamax in the state of a moving motorcycle, the researcher obtained the data as presented in Table 3.

Table 3: Test results of fuel consumption on a moving motorcycle

\begin{tabular}{lccc}
\hline \multicolumn{1}{c}{ Fuel } & $\begin{array}{c}\text { Amount of } \\
\text { Fuel }(\mathbf{m l})\end{array}$ & $\begin{array}{c}\text { Speed } \\
(\mathbf{k m} / \mathbf{h})\end{array}$ & $\begin{array}{c}\text { Mileage } \\
(\mathbf{k m})\end{array}$ \\
\hline Pure Pertalite & 300 & 40 & 13.9 \\
Pertalite + FFPB & 300 & 40 & 14.9 \\
Pure Pertamax & 300 & 40 & 14.6 \\
\hline
\end{tabular}

The data from Table 3 were then used by researchers as material to graph the comparison of consumption levels between pure Pertalite, Pertalite mixed with FFPB and pure Pertamax based on mileage on a moving motorcycle, as shown in Figure 3.

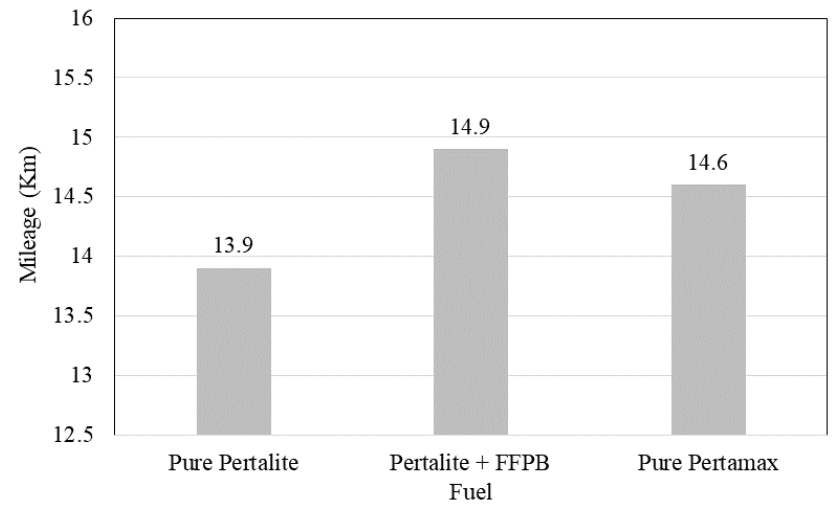

Figure 3: Comparison of fuel consumption rate based on mileage

From Table 2 and Figure 3, it can be explained that:

1) The first test was carried out using $300 \mathrm{ml}$ of pure Pertalite on a motorcycle to be moved/forwarded at a speed of 40 $\mathrm{km} / \mathrm{h}$ and a tolerance of $\pm 5 \mathrm{~km} / \mathrm{h}$. Mileage obtained was 13.9 kilometers $(\mathrm{km})$ to spend $300 \mathrm{ml}$ of pure Pertalite.

2) The second test was carried out using Pertalite as much as $300 \mathrm{ml}$ mixed with FFPB, then the motorcycle was moved/forwarded at a speed of $40 \mathrm{~km} / \mathrm{h}$ and a tolerance of
$5 \mathrm{~km} / \mathrm{h}$. From the test results, it was found that the motorbike traveled 14.9 kilometers $(\mathrm{km})$ to spend the fuel.

3) In the third test, $300 \mathrm{ml}$ of pure Pertamax was used as a motorcycle fuel driven at a speed of $40 \mathrm{~km} / \mathrm{h}$ and a tolerance of $5 \mathrm{~km} / \mathrm{h}$. From the test results, the motorbike traveled 14.6 kilometers $(\mathrm{km})$ to spend the fuel.

From the third type of fuel testing on the condition of a moving motorcycle, as presented in Table 3 and Figure 3, pure Pertalite has the shortest mileage. This means that pure Pertalite has the lowest efficiency compared to the other two types of fuel.

Pertalite mixed with FFPB produces more mileage than using pure Pertalite. Thus, the addition of FFPB to Pertalite was proven to be able to increase efficiency by a percentage of $6.7 \%$ compared to pure Pertalite. The higher octane value of Pertalite causes this due to the addition of FFPB. The FFPB additive containing the primary element methyl ester can increase the Pertalite octane value. So that the higher the octane value, the perfect combustion, and the higher the efficiency.

Pure Pertamax produces shorter mileage when compared to Pertalite mixed with FFPB but not too significant (only 2\%). Means, the addition of FFPB to Pertalite, can increase its efficiency beyond pure Pertamax on a running motorcycle.

\section{CONCLUSION}

The results of research on the effect of the addition of FFPB on Pertalite to motorcycle fuel consumption indicate that the addition of FFPB to Pertalite increases the efficiency of fuel consumption and can be comparable to Pertamax. This was due to an increase in octane when FFPB was added to Pertalite, so the combustion process becomes faster.

\section{ACKNOWLEDGEMENTS}

Authors thank to Universitas Muhammadiyah Sidoarjo for supporting research financially.

\section{REFERENCES}

[1] I. W. Sugita, D. R. B. Syaka, and A. I. Wahyudi, "Effect of Pertalite-Methanol Blends on Performance and Exhaust Emission of a Four-stroke 125 CC Motorcycle Engine," KnE Social Sciences, pp. 384-393, 2019.

[2] Y. Prayogi and N. Sinaga, "Performance and exhaust gas emission of gasoline engine fueled by gasoline, acetone and wet methanol blends," in IOP Conference Series: Materials Science and Engineering, 2019, vol. 535, no. 1, p. 12013.

[3] S. Abikusna, B. Sugiarto, D. Suntoro, and ..., "Low grade bioethanol for fuel mixing on gasoline engine 
using distillation process," AIP Conference ..., 2017.

[4] J. B. Heywood, "Combustion engine fundamentals," $1^{a}$ Edição Estados Unidos, 1988.

[5] B. C. Purnomo and N. Widodo, "Torque and Power Characteristics of Single Piston LPG-Fueled Engines on Variations of Ignition Timing," Automotive Experiences, vol. 2, no. 1, pp. 22-27, 2019. https://doi.org/10.31603/ae.v2i1.2632

[6] H. Nurrohman, B. Susanto, and N. Widodo, "Studi Eksperimen Variasi Tekanan Bahan Bakar Terhadap Emisi pada Mesin EFI," Automotive Experiences, vol. 1, no. 2, pp. 53-57, 2018.

[7] E. Suryono, I. H. A. Nagoro, and D. Y. S. Wicaksana, "Analisis Temperatur Bahan Bakar pada Reaktor Hydrocarbon Crack System Terhadap Hasil Emisi Engine 4A-FE," Automotive Experiences, vol. 1, no. 3, pp. 58-63, 2018.

[8] J. Hu, Z. Jiang, and H. Liao, "Preventive maintenance of a single machine system working under piecewise constant operating condition," Reliability Engineering \& System Safety, vol. 168, pp. 105-115, 2017.

[9] W. W. Pulkrabek, "Engineering fundamentals of the internal combustion engine." 2004.

[10] J. E. Anderson et al., "High octane number ethanol--gasoline blends: Quantifying the potential benefits in the United States," Fuel, vol. 97, pp. 585-594, 2012.

[11] J. D. Halderman and C. D. Mitchell, Automotive technology. Pearson, 2014.

[12] H. Li et al., "An investigation of the combustion process of a heavy-duty dual fuel engine supplemented with natural gas or hydrogen," International Journal of Hydrogen Energy, vol. 42, no. 5, pp. 3352-3362, 2017.

[13] E. Alptekin, "Emission, injection and combustion characteristics of biodiesel and oxygenated fuel blends in a common rail diesel engine," Energy, vol. 119, pp. 44-52, 2017. https://doi.org/10.1016/j.energy.2016.12.069

[14] A. Elfasakhany, "Performance and emissions analysis on using acetone-gasoline fuel blends in spark-ignition engine," Engineering Science and Technology, an International Journal, vol. 19, no. 3, pp. 1224-1232, 2016.

[15] H. Nasrul, U. Fazara, M. Ali, A. Che Zulzikrami Azner, and A. Razi, "Characterization of bio-oil from palm kernel shell pyrolysis," 2014.

[16] S. Abikusna, B. Sugiarto, and A. Zulfan, "Fuel consumption and emission on fuel mixer low-grade bioethanol fuelled motorcycle," in MATEC Web of Conferences, 2017, vol. 101, p. 2017.

[17] S. Senthilkumar, G. Sivakumar, and S. Manoharan, "Investigation of palm methyl-ester bio-diesel with additive on performance and emission characteristics of a diesel engine under 8-mode testing cycle," Alexandria Engineering Journal, vol. 54, no. 3, pp. 423-428, 2015.

[18] H. A. Dabbagh, F. Ghobadi, M. R. Ehsani, and M. Moradmand, "The influence of ester additives on the properties of gasoline," Fuel, vol. 104, pp. 216-223, 2013.

https://doi.org/10.1016/j.fuel.2012.09.056 